\title{
ECOLOGICAL CONDITIONS OF BIRD HABITATS IN THE SOUTH OF UKRAINE
}

\author{
UDC 502/504:598.2(477)
}

\section{Elnara M. Ayubova}

Tavria State Agrotechnological University, Ukraine

\begin{abstract}
The publication focuses on the study of ecological conditions of bird habitats in the steppe zone of Ukraine. The material is based on the original observations in the north-western part of the Azov Sea region over the period 2009-2018 and on the data from relevant literature sources. The impact of changes in ecological conditions of bird habitats was considered and analyzed. The objectives were to show stages of changes in ecological conditions of the Ukrainian steppe and to carry out a comparative analysis of original ornithological data with the data of other authors.
\end{abstract}

Key words: ecological conditions, avifauna, steppe zone, forest belts, agrolandscape

\section{INTRODUCTION}

The Ukrainian steppe zone is located in the south of Ukraine and stretches from the lower Danube to spurs of the Central Russian Upland, covering an area of above 1,000 $\mathrm{km}$ and being about $100 \mathrm{~km}$ wide at the west and up to $300-450 \mathrm{~km}$ at the east. It encompasses Kherson, Zaporizhzhia, Dnipropetrovsk, Donetsk and Luhansk administrative regions, parts of Odesa, Mykolaiv, Poltava, Kyrovohrad, Kharkiv regions, and the northern plain territory of the Crimea. The climate is continental and arid. The precipitation is scanty, falling predominantly in summer as downpours. Hot dry winds and dust storms are frequent. Insufficient and uneven moisture, thin snow cover (snow is blown out and accumulates in gullies and shrub thickets) are characteristic features. Soils are represented by chernozems and chestnut soils formed under arid conditions. In the past, the steppe areas of Ukraine had well-developed grass vegetation cover that further served as the basis for the formation of chernozem (forb-fescue-feather grass, wormwood-gramineous steppes) [3].

The transformation of steppe regions was associated with the development of virgin lands, when a major part of soil was cultivated and the steppe soon lost its natural appearance. The deteriorating situation with soils (aridization of all agricultural zones)

Received November 3, 2018 / Accepted December 26, 2018

Corresponding author: Elnara M. Ayubova

Tavria State Agrotechnological University, Bohdan Khmelnytsky Ave., 18, Melitopol, Zaporizhzhia Region, Ukraine, 72310

E-mail: elnaraaubova8181@gmail.com 
has eventually required the creation of shelter belts. Planted forest landscapes not only facilitated the ecological functions of natural forests but also performed melioration, water and field protection and other functions.

The current picture of Ukrainian steppes is represented by agrolandscapes, and only $4 \%$ of the territory remains untouched. A major part of the uncultivated territory consists of steppe areas unsuitable for agriculture, varieties of steppe communities on rocky substrates, and steep slopes of steppe gullies. Many of them are included in the structure of protected areas and monuments of nature.

\section{MATERIAL AND METHODS}

Material of this research is based on original observations carried out in roadside, field and riparian shelterbelts and gullies with natural shrubs remained along the banks of the Molochnha River and the rivers flowing into it. The data, collected by the author during 20092018, and relevant scientific publications were used. Control transects 1-2 km long were selected in shelter belts of different type and age in the vicinity of Melitopol City within a radius up to $50 \mathrm{~km}$. The birds were counted doubly in April-June according to standard methods [6]. When describing the shelter belts, the species composition of trees and shrubs, their age, type and structure, proximity to bodies of water and settlements, type and intensity of their usage for human purposes were recorded. The study area encompassed roadside shelter belts along the highways $\mathrm{K}-150-$ Moscow-Simferopol, M-14-Rostov-Odesa-Reni (along the villages of Udachne, Novohorodka, Lazurne, Zolota Dolyna, Polianovka), Zaporizhzhia (Obylne Village) Control plots of riparian shelter belts (Polianovka Village) along the shores of Molochnyi Liman were also included. The data were collected using the method of linear transects. Pedestrian and automobile (at a speed of 30-60 km/h) observations were made. Scientific bird names are given according to H.V. Fesenko and A.A. Bokotey [14].

\section{RESULTS AND DISCUSSION}

For a long time, steppe biocoenoses dominated in the study area, delineated by floodplains of small rivers with meadow and underdeveloped tree-shrub vegetation. The latter was represented by willows, poplars and thickets of steppe shrubs (blackthorn, dwarf Russian almond, caragana, etc.). Natural forests in the steppe were present only as separate islets, growing in the river floodplains or as coppices in the mouths of river gullies and ravines. The avifauna was represented by the partridge, great bustard, little bustard, some species of larks, steppe eagle, etc.

In the steppe, since the times of the Trypillian culture (5th century AD) people were engaged in cattle breeding and farming, grew wheat and barley, raised pigs, cows, and, sheep, hunting and fishing [16]. The nomadic Scythians, Huns, Khazars, Mongols, Tatars, Polovtsians, and finally, the Slavs, replacing each other, influenced the nature so the steppe acquired its own characteristics and ecological conditions. By means of wars, peoples conquered these lands, subjecting them to burning and reclamation of ponds and wells. Intensive development of cattle breeding rapidly converted virgin areas into pastures for bovine animals and small cattle. The domestic cattle grazing (in particular, sheep and goats) and the prevalence of high numbers of wild ungulates (tarpan, saiga) hindered the 
development of lush vegetation. The steppe flora was characterized by a low grass cover with the dominance of narrow-leaved cereals (feather grass, fescue, June grass, sedge, meadow grass). Shrub thickets were formed by the steppe cherry, blackthorn, Laburnum, Spireae, and the wild rose.

By the end of the 18th century the situation in the steppe had changed due to the rapid growth of the settled population consisting of Slavs; the number of nomads declined. In the late 18th - early 19th centuries a significant part of the territory was occupied by arable lands. On the fields with cultivated cereals, flax, gourds and melons, some species of aboriginal wild animals and birds could not exist, and their range was shrinking under the development of agriculture. The livestock raising and frequent deaths of animals caused by diseases provoked the appearance of high numbers of birds of prey feeding on carrion [17].

By the middle of the 19th century, especially after the reform of 1861, the capitalist relations demonstrated a vigorous growth, both in industry and agriculture. The intensive building of bridges and villages, road network and giant reservoirs was initiated; also, a network of canals has been constructed. The situation in the Ukrainian steppes changed and, the steppe lands were converted into agrocoenoses. In fact, by the early 20th century all the lands suitable for agriculture had been developed. These transformations in the arid region were soon followed by strong wind storms, resulted in the reduction in crop yields thereby necessitating the introduction of erosion control measures which included forest plantations in the form of small groves and shelter belts. Since that time in the steppe regions the works have been focused on planting field shelter belts, sand afforestation, creation of commercially important forests, designing green zones around cities and industrial centers, along the riverbanks, shores of canals and reservoirs.

The first forest plantations (on the slopes of Kashlahach Gully) consisted of the oak, maple and ash. Their area covered circa 157 ha, and it was they which became the basis for the Velyko-Anadolskyi Forest. Thus, the largest artificial forests included VelykoAnadolskyi (1843) -2,727 ha, Volodymyrivskyi (1873) -2,581 ha, Ratsynskyi (1875) 1,786 ha, Volodarskyi (1878) - 1,547 ha, Bolshe-Mykhailivskyi (1874) -1,216 ha, Dalnytskyi (1957) -1,204 ha, Arkhanhelskyi (1846) -1,200 ha, Staro-Berdianskyi (1846) 996 ha, etc. Prior to the World War I in 1914, about 1,500 ha of field shelter belts had been planted in Ukraine. By 1933, their total area had reached 14,700 ha, and by 1941 - almost 270,000 ha [7].

With the beginning of the World War II, a significant part of the plantations disappeared or became unusable. However, the post-war revival of the national economy resumed the growing of field shelter belts with even greater force. Over 400,000 ha of shelter belts were planted, about 1.4 million ha of lands were reforested (of them 150,000 ha along the riverbanks and shores of reservoirs) [7]. All these measures have crucially changed ecological conditions of the steppe zone.

The trees and shrubs in the forests and shelter belts consisted of the oak (Quercus robur), ash (Fraxinus excelsior), pine (Pinus sylvestris L.), white locust (Robinia pseudoacacia), black (Populus nigra) and silver poplars (P. alba). The birch (Betula pendula), hornbeam (Carpinus betulus), maples - Norway (Acer platanoides), field (A. campestre), Tatar (A. tataricum), ash -leaved (A. negundo), European crab apple (Malus sylvestris), pear (Pyrus communis), Virginian juniper (Juniperus virginiana), silverberry (Elaeagnus commutata), locust (Gleditchia triacantha), etc. were less common. The undergrowth included the hawthorn (Crataegus aestivalis), elderberry (Sambucus nigra), spindle (Euoaymus europaeus), privet (Ligustrum vulgare), cherry (Cerasus fruticosa), golden currant (Ribes aureum), blackthorn 
(Prunus spinosa), apricot (Prunus spinosa) and other species. There were also changes in the avifauna structure since a number of species had practically disappeared: black grouse (Tympanuchus cupido), great bustard (Otis tarda), steppe eagle (Aquila rapax), little bustard (Tetrax tetrax), Caspian gull (Larus cachinnans), black (Melanocorypha yeltoniensis) and white-winged larks (M. leucoptera), black-winged pratincole (Glareola nordmanni) etc. [12].

The avifauna of shelter belts and artificial forest stands has been repeatedly studied by a number of authors. M.P. Akimov (1934) and A.N. Melnichenko (1938) were among the first. In the early years of massive forest planting, the avifauna observations were particularly intensive (Volchanetsky, 1940, 1950, 1952, 1954, 1968; Budnichenko, 1949, 1955, 1965; Lisetsky, 1952, 1959; Orlov, 1955; Voinstvensky, 1960, 1967, 1968; Stakhovsky, 1959, 1960, 1969). As for subsequent years, the following studies should be mentioned: Formozov, 1971; Filonov, 1972; Gubkin 1975, 1978; Babenko, Kravtsov, 1979; Bulakhov, 1980; Koshelev, Peresadko, 2011; Koshelev, 1988, 2005; Gavrilenko, Listopadsky, 2012; Listopadsky, 2011, 2014, 2015, Petrovich, 2014, etc.

In 1950 (May-June), I. B. Volchanetsky with an expedition team have studied young shelter belts, aged 10-15 years. They made a number of conclusions stating that the avifauna of the shelter belts was generally poor in species and abundance, and the proximity to forest massifs induced decrease in the abundance of shrub-nesting birds in favor of forest species [5]. On the other hand, the shelter belts distanced from the forest massifs were rich in birds, since for the migratory and nomadic species the shelter belts appear to be "islands" in the open steppe landscape. The fact that the trees were young and not mature also played its role in the absence of hollow-nesting birds. The authors have also studied the impact of the avifauna of shelter belts on cultivated crops. Stomachs of most birds contained insects living in the nearest fields, rarely there were inhabitants of tree plantations. Foraging of insectivorous birds is closely associated with the maturity degree of the plantations. Initially, when trees and shrubs are still low, they support the steppe or field birds grabbing insects from the ground and grass (larks, tawny pipit (Anthus campestris), ortolan bunting (Emberiza hortulana), common whitethroat (Sylvia communis), whinchat (Saxicola rubetra), red-backed shrike (Lanius collurio), quail (Coturnix coturnix), partridge (Perdix perdix) etc.). In maturing plantations, dendrophilous species of insects appear followed by the birds which feed on twigs and leaves (garden (S. borin) and barred warblers (S. nisoria)) emerge. Then appear insects requiring thick trunks and, correspondingly, hollow-nesting birds (tits (Parus major) and woodpeckers (Dendrocopos major)), although for the latter species the availability of old habitable trees is a crucial factor [5]. The studies of these shelter belts carried out during 1952-1967 (Volchanetsky, Lisetsky, Kholupyak, 1970; Orlov, 1955), have revealed that the avian population had been replenished that was in particular associated with logging of riverine forests for the construction of the bed of Kakhovske Reservoir. The factors limiting the presence of a full set of the avifauna are the arid steppe, distant location from bird migratory routes, insufficient food supply, neglected and damaged plantations. Another factor is availability of watering sites. Obviously, with at least some source of moisture the bird population is more diverse and numerous [4].

Further investigations of these areas (including our observations) have shown the increase in abundance of some species including the rook (Corvus frugilegus). The species started breeding in the region in the early 20th after the cultivation of steppes and tree planting [9]. Rook colonies attract breeding of the long-eared owl (Asio otus), kestrel (Falco tinnuculus), red-footed falcon (F. Vespertinus), hooded crow (C. cornix), lesser grey shrike (Lanius minor), tree sparrow (Passer domesticus). Egrets (Ardea cinerea, 
Egretta alba, E. Garzetta) and night herons (Nycticorax nycticorax) are recorded, while increasing numbers of magpies (Pica pica), provide nests for small falcons (F. cherrug, F. Subbuteo, F. Naumanni), owls, and tree sparrows. These latter species also grew in numbers. Bird counts carried by experts (Koshelev, 1988-2005; M. A. Listopadsky, 2011, 2014, 2015; O.Z. Petrovich, 2014 et al.) have revealed that the growth of dense shrub thickets provoked the formation of a new bird community consisting of 42-54 species, earlier recorded only on passage [8]. Some breeding species are common and numerous, others breed only in some years, by single pairs and not in all shelter belts.

To-date, almost $90 \%$ of the Ukrainian steppe is cultivated and represented by the agrocoenoses delineated by shelter belts. Emergence of new biogeocoenoses (artificial shelter belts, forest massifs, cascade of reservoirs at the Dnieper) has led to the changes in different zoo- and avian communities. The steppe community has noticeably changed: such species as the little bustard, stone curlew (Burhinus oedicnemus), demoiselle crane (Anthropoides virgo) and great bustard declined. Many common steppe species began to penetrate in the forest community, some adapted to agrocoenoses, while others were forced out [11]. In present-day realities, the majority of arable lands is occupied by monocultures (sunflower or cereals in our region), and only some species can exist under such conditions (protective and feeding). The processes, associated with agricultural activity (haymaking, application of weed chemicals, pesticides, etc.) provoke dramatic changes in ecological conditions of fauna. A number of authors (Belik, 1997; Formozov, 1937) have indicated a direct and indirect influence of agricultural activities on the avifauna structure. Haymaking often leads to the destruction of many nests of quails and some passerines. It removes the high grass which gave shelter and protecton for rich fauna. Abundant resources of green and corny forage is taken out from the mown area. Open areas, appearing instead, have an adverse impact on the protection potential of small rodents and reduce bird food resources. Some species (quail, partridge, great bustard, etc.), closely associated with agricultural areas, often die under mowing machines. Because of the dramatic deterioration of protection capacities of mown areas, the species which used to find shelter in a high grass have to move to new areas. However, for many bird speces these changes could be beneficial providing them with opportinity to catch the prey that was otherwise well concealed before haymaking.

The impact of pesticides and weed chemicals on the distribution and population dynamics of some bird species should be mentioned (Churkina, 1964, 1967; Ostroumov, 1983; Belik, 1993, 1997 et al.). According to the data of these authors, the application of pesticides in order to supress hotbeds of agricultural pests has lead to mass mortality of birds and decrease in their population abundance. After elimination of steppe locust (Acridoidea) swarms in the south of Ukraine, the range and numbers of the rose starling (Pastor roseus) and kestrel (F. Naumanni), feeding mainly on these insects, have sharply decreased. Apart from the direct impact, the indirect implication lies in using rodenticides to exterminate little sousliks (Spermophilus pygmaeus) (gas treatment of holes). The extinction of rodens in vast areas has resulted in the decrease of populations of the steppe eagle and long-legged buzzard feeding mainly on sousliks; the number of the isabelline wheatear (Oenanthe isabellina) nesting in their holes dropped as well [1]. 


\section{CONCLUSIONS}

Thus, the environmental conditions of the steppe zone of Ukraine have undergone significant changes. The steppe biogeocenosis had been earlier favourable to support a significant number of the common crane, great bustard, little bustard, larks, steppe eagle, etc. However, the destruction of the steppe biota left few suitable habitats for these species. Due to the construction of reservoirs and canals, significant areas of natural forests in floodplains of the Dnieper, Dniester, Southern Buh and other rivers were destroyed. On the contrary, artificial forest massifs were created in the steppe zone, and lots of field, erosionprevention, and riparian sheter belts were planted over the years. Along with artificial forests, they have created a chain of forest plantations, thereby providing many birds with opportunity to nest in trees.

Optimal conditions for the population growth of individual species have appeared in agrocenoses, artificial wetlands, forest massifs, shelter belts, parks, and poles of power lines. Planted forests and shelter belts are massively occupied by such species as raven, hooded crow, magpie, wood pigeon, goshawk, turtle dove, and blackbird, which are unusual for the steppe zone. Hollow concrete poles of power lines turned out to be very convenient for nesting jackdaws, while ravens and saker falcons began nesting on trussed poles. Small birds, perching on different elements of the poles, contribute to the formation of trees and shrubs as a result of their trophic activity. Shrub thickets of shelter belts contribute to the appearance and distribution of the common whitethroat, garden and barred warblers, nightingale, and red-backed shrike. Artificial reservoirs attract great cormorants, grey heron, great egret, little egret and night heron.

The intensive economic activity, directed at the steppe zone development, have completely transformed the steppe biota and dramatically reduced abundance of indigenous fauna species. Some of them have completely disappeared, while for others the beneficial habitat conditions have been formed.

\section{REFERENCES}

1. Belik, V. P. (2009). Birds of planted forests of the steppe Ciscaucasia. Krivoy Rog: Mineral. 216 p. [in Russian]

2. Budnichenko, A. S. (1965). Birds of planted forests. Voronezh. 324 p. [in Russian]

3. Volokh, A. M. (2006). Dynamics and current state of habitats of game mammals in the steppe zone of Ukraine. Scientific Bulletin of National Agrarian University, 93, 34-49. [in Russian]

4. Volchanetsky, I. B., Lisetsky, A. S., \& Kholulyak, Yu. K. (1970). On the formation of avifauna of artificial plantations of South Ukraine over the period from 1936 to 1967. Vestnik Zoologii. [in Russian]

5. Volchanetsky, I. B. (1952). On the formation of bird and mammal fauna of young shelter belts in arid regions of Left-bank Ukraine. Transactions of Scientific-Research Institute of Kharkov State University. [in Russian]

6. Gudina, A. N. (1999). Count techniques of breeding birds. Zaporozhye: Dikoe Pole. 242 c. [in Russian]

7. Koptev, V.I., \& Lishchenko, A.A. (1989). Field-protective afforestation. Kyiv: Urozhai. 168 p. [in Ukrainian]

8. Koshelev, A. I. (2005). Bird communities of planted forests of the northern part of the Azov Sea region: development, dynamics and contribution to the maintenance of regional diversity. In The biodiversity and role of zoocoenosis in natural and anthropogenic ecosystems. Proceedings of the 3d International Scientific Conference (pp. 422-425). Dnipropetrovsk: Dnipropetrovsk National University Press. [in Russian]

9. Koshelev, A. I., Peresadko, L. V., Koshelev, V. A., Pokusa, R. V., \& Kopylova, T. V. (2005). Anthropogenic transformation of landscapes of the northern part of the Azov Sea region, booms and recessions in the number of common vertebrate species and their impact on the zoocenoses structure In The biodiversity and role of zoocoenosis in natural and anthropogenic ecosystems. Proceedings of the 3d International Scientific Conference (pp. 123-125). Dnipropetrovsk: Dnipropetrovsk National University Press. [in Russian] 
10. Lystopadskyi, M. A. (2012). On the formation of current structure of avian coenoses of tree plantations in Askania Nova Biosphere Reserve. Bulletin of Zaporizhzhia National University, 3, 115-135. [in Ukrainian]

11. Myasoedova, O. M., \& Bulakhov, V. L. (1975). Penetration of forest species of terrestrial vertebrates in different biogeocoenoses of the steppe zone of the Dnieper River region. Environmental conservation and melioration of the middle part of the Dnieper River region. Collection of scientific papers of the Geographical Society of the USSR (pp. 45-50). Leningrad. [in Russian]

12. Orlov, P. (1955). Materials on the avifauna of planted forests and shelter belts of Melitopol District. Scientific Notes of Melitopol State Pedagogical Institute, 2, 55-65. [in Ukrainian]

13. Petrovich, O. Z. (2014). Birds of shelter belts in Voznesenka District, Mykolaiv Region in the breeding season. Bulletin of Askania Nova Biosphere Reserve. [in Ukrainian]

14. Fesenko, H.V., \& Bokotey, A. A. (2000). Annotated list of Ukrainian scientific names of birds of Ukrainian fauna. Kyiv-Lviv, 44 p. [in Ukrainian]

15. Koshelev, A. I., Peresadko, L. V., Pisanets, A. M., Fesenko, Yu. E., \& Yust, T.S. (2003). Fragmentation and defragmentation of landscapes of South Ukraine and biodiversity dynamics of vertebrates. In Dynamics of scientific studies 2003. Proceedings of the 2nd international scientific-practical conference (vol. 14. Ecology, pp. 3-6). Dnipropetrovsk: Nauka i Osvita, 2003. [in Russian]

16. Formosov, A.N. (1981). Changes in natural conditions of the steppe south of European part of the USSR for the last hundred years and some features of current steppe fauna. In Issues of ecology and geography of animals (pp. 52-119). Moscow: Nauka. [in Russian]

17. Chibilev, A.A. (1998) Steppes of Northern Eurasia. Ecological-geographical essay and bibliography. Yekaterinburg: the Urals department of the Russian Academy of Sciences. Institute of the Steppe. [in Russian]

\section{EKOLOŠKI USLOVI STANIŠTA PTICA NA JUGU UKRAJINE}

Tema ovog rada je studija ekoloških uslova staništa ptica u stepskoj zoni Ukrajine. Materijal se zasniva na originalnim istraživanjima $i$ observacijama ptica u jugozapadnom delu regiona Azovskog mora u periodu od 2009. do 2018., kao i na podacima iz relevatnih izvora literature. U radu je analiziran uticaj promena ekoloških uslova u staništima ptica. Cilj rada je da predstavi korake u promenama ekoloških uslova stepskih regiona u Ukrajini, kao $i$ da sprovede komparativnu analizu originalnih orintoloških podataka sa podacima ostalih autora.

Ključne reči: ekološki uslovi, avifauna, stepska zona, šumski pojas, poljoprivredni pejzaž 